\title{
Fruit drop: The role of inner agents and environmental factors in the drop of flowers and fruits
}

\author{
Racskó, J. ${ }^{1}$, Leite, G.B. ${ }^{2}$, Petri, J.L. ${ }^{2}$, Zhongfu, S. ${ }^{3}$, Wang, Y. ${ }^{3}$, Szabó, Z. ${ }^{1}$, \\ Soltész, M. ${ }^{4} \&$ Nyéki, J. ${ }^{1}$ \\ ${ }^{1}$ University of Debrecen, Institute for Extension and Development, H-4032 Debrecen, Böszörményi st. 138. \\ Hungary,E-mail:racsko@agr.unideb.hu \\ ${ }^{2}$ EPAGRI, Experimental Station of Caçador, Rua Abílio Franco 1500 Bairro Bom Sucesso, Caixa Postal 591, \\ 89500-000 Caçador,SC,Brasil,E-mail: gabriel@epagri.sc.gov.br \\ ${ }^{3}$ Chinese Academy of Agricultural Sciences, No. 12, Zhongguancun South Street, Beijing 100081, P.R. China, \\ Email:sunzf@263.net \\ ${ }^{4}$ College of Kecskemét, Faculty of Horticulture, Fruitgrowing Department, \\ H-6000 Kecskemét,Erdei Ferenc tér4-6.Hungary,E-mail: soltesz.miklos@kfk.kefo.hu
}

Summary: The basic conditions of fruit set (synchronic bloom, transfer of pollen, etc.) still do decide definitely the fate of the flower (Cano-Medrano \& Darnell, 1998) in spite of the best weather conditions (Stösser, 2002). Beyond a set quantity of fruits, the tree is unable to bring up larger load. A system of autoregulation works in the background and causes the drop of a fraction of fruits in spite of the accomplished fertilisation and the equality of physiological precedents (Soltész, 1997). There are also basically genetic agents in action. The further development of fruits maintained on the tree depends mainly on the growing conditions (e.g. water, supply of nutrients, weather adversities, pruning, fruit thinning, biotic damages, etc.), which may cause on their own turn fruit drop especially at the time of approaching maturity.

Key words: fruit drop, seed content, competition between plant organs, environmental factors, diseases, pests

\section{The role of inner agents in the drop of flowers and fruits}

\section{Conditions of pollination and fertilisation}

The outstanding importance of pollination and fertilisation of flowers in especially observed in walnut (Szentiványi, 1990b). The peculiar case of "overpollination" causing the abortion of female flowers is observed, when a large mass of viable pollen is recognised as being deleterious (Pór \& Pór, 1990; Szentiványi, 1990a). Pollen quantities less than optimal seem to be even more favourable because the possibility of apomictic seed formation, which may compensate for the deficiency.

The disadvantageous effect of supernumerary pollen grains on the stigmata was first reported by Kavetskaja \& Tokar (1963). They observed that when more than 10-18 pollen gains are cached by the two lobes of the stigma, the latter faded severely just the next day and about $93 \%$ of stigmata died and dried out at the third day causing the drop of the respective female flowers. The rate of fading is closely related to the amount of pollen involved. Unviable pollen causes the same as the viable one. The abortion of stigmata is caused lastly by the high concentration of ethylene (Szentiványi, 2000). In the case of young female flowers, the lobes of the stigma are still closed, but as a consequence of much pollen, they may fade without expanding and are shed.

After the recognition of the above fact, a couple of papers appeared dealing with that phenomenon (Catlin et al., 1987; Catlin \& Polito, 1989; Catlin \& Olsson, 1990; Deng et al., 1991; McGranahan et al., 1994; Rovira \& Aleta, 1997).

The time of pollination and of fertilisation are not indifferent from the point of view of subsequent fruit drop. Ortega et al. (2004) claimed that in almonds, fruit drop is more frequent if the pollination is performed near to the end of the effective pollination period (EPP), which means in the experiments, the $4^{\text {th }}$ or $6^{\text {th }}$ day after the emasculation of flower buds.

In pear, Miranda et al. (2005) observed that the number of viable pistils within the flower did not influence fruit drop, referring to the varieties 'Blanquilla' and 'Conference'. The excision of pistils did not impair the fruit set of the respective flower.

Sweet cherries of late maturity displayed higher rates of fruit drop, as a rule, which is attributed to the abortion of the embryo. In the super-early cherries, embryo abortion occurs often during the second phase of pericarp growth, subsequently, the remaining fruits are maintained until 
maturity. The cause of abortion is the supposed consequence of the competition for resources between the seed and the pericarp (Bargioni, 1978). In early ripening cherries, the degeneration of seed primordia may endure until harvest when the pit of the stone is already shrivelled, whereas similar anomalies end in fruit drop for late ripening cherry varieties (Bargioni, 1982).

Charitonova \& Spicyn (1976) classified fruit drop of cherry according to the following groups: abnormal flowers with unviable ovule, parthenocarpy, and fruits with underdeveloped embryo. In the variety 'Napoleon', preharvest fruit drop is observed caused by the degeneration of the endosperm (Guerro-Pietro, 1984).

Redalen (1984) stated a close correlation between fruit set data checked after the subsequent periods of fruit drop. According to Tylus (1975), preharvest fruit drop is observed only in varieties characterised by high rates of fruit set.

In black currants, exploration of fruit drop due to insufficient fertilisation started with the research of Wellington et al. (cit. Brózik \& Nyéki, 1975). They concluded that the post-bloom fruit drop is due to the autoincompatibility of the varieties.

Cano-Medrano \& Darnell (1998) dealing with cranberry, found a low $(5 \%)$ frequency of fruit drop if abundant alien (not self) pollen was available. Fruit set was stimulated also by the application of GA. On the contrary, the rate of fruit drop was high if the pollen source was restricted and autopollination was forced.

Insufficient fertilisation is not expressed by fruit drop in strawberry, raspberry and blackberry but by producing deformed small fruits. Gardner et al. (1952) explained the phenomenon with the fact that the flowers may set fruit or not, there are no other alternatives. Schuster (cit. Gardner, 1952) contended that after the primary flowers of the strawberry having been set, the secondary flowers have less chance to set. They are not dropped, but remain rudimentary, corresponding to first drop of flowers after bloom (Soltész, 1997).

\section{Seed content of fruits}

During the initial phase of fruit growth, the development of seeds is of special interest from the point of view of fruit drop (Luckwill, 1948, 1953, Brittain, 1933; Tydemann, 1943). On the contrary, Abruzzese et al. (1995) did not find significant difference between the seed content of fruits dropped and maintained on the tree.

Seeds, especially their endosperm, are the sites of synthesis, where growth substances are produced. First, as the endosperm is formed, the fruits start growing intensely under the effect of auxin. Subsequently, the embryo consumes the endosperm, which is coincident with a lag phase of fruit growth often associated with fruit drop. After the embryo have completed its growth, the formation of the secondary endosperm appears, which continues to produce auxin inhibiting abscission its turn.

Wareing \& Phillips (1978) stated that auxin absorbs not only organic substances but influences also the distribution of cytokinins flowing to the fruit, which is an active sink of metabolites. The young organs compete successfully with the older parts of the tree, but the elimination of the seeds (by excising) changes drastically that relation (Szalai, 1994).

Fruit species producing fruits containing more than one seed (apple, pear, quince or currants) drop preferably those fruits, which contain the less number of seeds. Therefore the varieties, which develop less seeds, genuinely, are more susceptible to environmental adversities, i.e. water stress, poor nutrition, etc. and are prone to drop fruits (Webber, 1923; Stösser, 2002). The most important precondition of the fruit to be maintained on the tree is its seed content. The critical number of seeds per fruit depends largely on the species or variety.

Teskey \& Shoemaker (1972) claimed that in apple, fruits containing less than 3 seeds are shed first when fruit set was abundant. Murneek (1987) too estimated the fruit drop of pears containing less than 3 seeds per fruit.

Fruits set by autopollination are less competitive than cross-pollinated ones. Under tropical conditions, less number of seeds may prove sufficient against the seedless (parthenocarpic) fruits.

In contrast to the former information, Abbruzzese et al. (1995) reported that in Italy, the apple variety 'Gloster' did not display correlation between fruit drop and seed content. However, the volume of seeds was half as high in the fruits shed than in the maintained ones.

Visser (cit. Brózik \& Nyéki, 1975) proved in pear a negative correlation between June drop and seed content of fruits. Comparing the number of viable seeds and fruit drop frequency, there were also cases with heavy rates of fruit drop in spite of many seeds per fruit (i.e. $3 \%$ of fruits were carried on to maturity only).

It is commonly recognised that in some varieties seedless fruits may appear, which is called parthenocarpy. Natural parthenocarpy is most known in pear, but may appear also in peach and apple. Those varieties set fruit less profusely and the competition between generative and vegetative organs as well as between fruits is more severe especially in the first phase of fruit drop after bloom (Strang et al., 1980; Westwood, 1993; Nyéki et al., 1994). The drop is especially accentuated when also fruits containing seeds are also growing on the same tree (Goldwin, 1994), their presence may exclude the existence of seedless fruits (Soltész, 2002).

Karnatz (cit. Soltész, 2003) examined a host of varieties and concluded that sufficient cross-pollination reduced the occurrence of seedless fruits to $0.5 \%$ as a mean of varieties (extreme values being $0.1-1.5 \%$ ). If the competition of fruits containing seed was excluded, parthenocarpic fruits appeared at a frequency of $4.7 \%$ as a mean with extreme values of 2.3 and $7.4 \%$.

As peculiar phenomena are registered cases when some of the seedless fruits do not grow nor drop but remain attached mummified. It was registered e.g. in 'Ingrid Marie', 'Elstar', 'Egri piros', 'Éva' and 'Jonager' apple varieties (Soltész, 1997). 
In one-seeded fruits - e.g. stone fruits - the seed content does not allow alternatives except yes and no in fertilisation. Fruit drop is timed by the development of the embryo(s) of the single stone. June drop becomes actual when the growth of embryo is intense. In normal fruits, the embryo grows continuously, whereas in dropped fruits, the size of the embryo stopped growing around one third of the normal size,

Tydemann \& Visser (cit. Brózik \& Nyéki, 1975) stated correlation in currants between the number of seeds per fruit and the size of the berry, as well as between the size of berry and the occurrence of drop. A close correlation was proved between the above phenomena (Wright, 1956; Williams \& Child, 1963). In black and red currant varieties, respective statistical proofs are produced by Klambt (cit. Brózik \& Nyéki, 1975).

Compared with black currant, red currant and gooseberry may developed fruits with less number of fruits and resist to fruit drop (Soltész, 1997).

The seed content of fruits - as auxin factories - are important factors of maintaining fruits on the tree. In seedless fruits that normal mechanism does not work. The role of the seeds was transferred to the fruit skin in orange and grape fruit. Its production of growth substances and physiology is far less intense than the regulating effect of the seeds, but it seems to be sufficient to prevent abortion of growing fruits (Monselise, 1978).

\section{Competition between the organs of plants}

\section{Competition between the vegetative and generative organs}

The relation between growth of shoots and fruit set is continuously changing during the growing season (Soltész, 2002). As generally recognised, the young fruit primordia still contain green chloroplasts and photosynthesise actively and contribute to their own provision (Szalai, 2003). Later, they loose that ability, and the function of source and of sink is assigned to different organs already (Atkinson et al., 2001). The products of photosynthesis from the leaves are transported by the phloem to the young fruits (Patrick, 1987). If the source and consequently the transport are restricted (e.g. when the leaves of the short shoots were discarded), the fruits will drop (Roper et al., 1987). On the contrary, Atkinson et al. (2001) reported instead of fruit drop a reduction of the fruit size. The low relation of leaf area per number of fruits caused fruit drop at the two-week interval of approaching harvest time only.

The number of fruits maintained on the tree depends on the sum of organic nutrients furnished by the leaves nearby, whereas the rest is doomed to be dropped (Papp, 2001). The photosynthetic apparatus of the tree is charged by both, the growing fruits as well as the growing shoots (Szalai, 2003). According to Petrov (1973), in peach, the fruit charge depends not so much from the volume of the fruits but rather from the number of fruits. The development of the endocarp of the stone is highly influenced by the competition of the vegetative organs of the tree (Timon, 1992). Brunner (1982), on the other hand, refers to the balance expressed by the ratio of leaves and fruits. At the time of the shed of petals, in apple 1-4 leaves are needed by one fruit set, around the June drop 10-15 leaves and at the end of fruit development 40 leaves provide the fruits. Relatively, higher leaf area is necessary for fruits set more than one per inflorescence and fruit drop did not occur (e.g. in 'Paulared', 'Summerred', 'Golden Delicious', 'Fuji', 'Fiesta') (Soltész, 1997).

The weak development of the leaf area around bloom (i.e. a low leaf/flower ratio) reduces the chances of fruit set and induces fruit drop. At 5-7 weeks after petals shed, the vigorous shoot growth (at warm weather) favours fruit drop. Later, on the other hand, slow growth of shoots may accentuate June drop by the insufficiency of leaf area. Apple varieties known to be weak in fruit set ('Cox's Orange Pippin', 'Starking' etc.) are afflicted by fruit drop caused by vigorous shoot growth even at a relatively low charge of fruits set. The inhibiting effect of the shoots is always influenced by their provision of nutrients on the tree or locally on the branch. Therefore, fruit drop may differ between trees of the same vigour of shoot growth (Feucht, 1970). Fruit drop may vary within the same tree according to the position of different branches (Soltész, 2002).

A clear correlation is evident in apple between the shoot growth and the tendency to fruit drop. Trees of strong shoot growth used to drop more fruit the weak growing trees, which may keep often supernumerary fruit primordia (mummies) on the fruiting structures. Poma \& Treccani (1982) proved the role of vigorous (water-) shoots in fruit drop. Vigorous shoot growth is responsible also for fruit drop, in blueberry, significantly (Eaton, 1967). Fruit drop in pecan, shoot growth and fruit drop is also related with each other (Isbell, 1928; Woodroof, 1928).

It is also an interesting observation that leaves may stimulate fruit abscission (Dávid, 1980). It is attributed to the translocation of ABA from the leaves to the fruits. Goren \& Goldschmidt (1970) indicated that mature leaves of Cytrus contain much ABA. The same was found in apple leaves by Pieniazek \& Rudnicki (1967), in Acer (maple) and Betula (birch) by Eagles \& Wareing (1964) and in Coleus by Chang (1971). Mature leaves are able to suppress the growth of apical buds even against the influence of $\mathrm{GS}_{3}$ spray (Cooper et al., 1969). At the same time, young leaves may delay the abscission of ripe fruits, whereas mature leaves promote the abscission of fruits by stimulating the transport of $\mathrm{ABA}$ (Dávid, 1980).

\section{Competition between the generative organs}

It is commonly accepted that in a large mass of flowers or fruit primordia, the accumulation of organic matter is not optimal causing a vigorous drop of fruit (Racskó, 2005). As a rule, a supernumerary bloom resulted in a low rate of fruit set (Pethö, 1993). The physiological explanation is forwarded that the flower or fruit set, which started growing earlier, 
becomes dominant in relation to other flower or fruits lagging relatively behind (Bubán, 2002). This type of dominance is called primogenous (Bangerth, 1990).

In the flower buds of the apple, the flower of apical position is always dominant and starts growing first (Bubán \& Faust, 1982). In this case, the dominance is due to its earliness rather than to its position. Most pear varieties (Dibuz, 1996), as well as gooseberry (Bubán, 1996) develop the first flower in basal position within the inflorescence and are corresponding to the apical flower of apple. Those flowers are the most developed, have the best chance to grow fruit, and are less exposed to be dropped. However, the excision of this first flower passes the same chances to the following flowers of the inflorescence (Goffinet et al., 1996; Ferree et al., 2001; Miranda et al., 2005a, 2005b).

The correlative signal of dominance induces the process of abscission by ABA and ethylene, as the latter is produced in senescent cells positioned distally to the respective abscission layer. As auxin (IAA) is acting against the effect of ethylene, the latter appears first at the basis of fruit stem as a factor preventing auxin to inhibit abscission in the AZ. Its further effects are:

- inhibition of the synthesis and translocation of IAA,

- stimulation of decomposition, binding and formation of conjugates with IAA.

All of those processes, except the binding of IAA are manifestly documented of being subject to the influence of ethylene by the fact that fruits treated with ethylene lost their IAA content significantly. The supposed mechanism, however, could not be explored under in vivo conditions yet.

In the processes the role of gibberellins is also involved because the diffusion of them from the growing tips and growing fruits is supposed to stimulate the movement of auxin (Bangerth, 1997).

The examination of the phenomenon of correlative dominance a significant role is assigned to the cytokinins too (Greene, 1989; Neri et al., 1992; Costa et al., 1995; Costa et al., 2001). Cytokinins applied to dominated fruits seem to be antagonists of IAA (Bangerth, 1993). Occasionally sprayed on apple, the number of fruits diminished (fruit drop increased), therefore, it may use for fruit thinning. The latter effect is supposed to stem from the stimulation of lateral branching (Greene \& Autio, 1990) or reduces the IAA export especially the dominated fruits, and as a result, fruit drop is induced (Gruber \& Bangerth, 1990).

\section{The role of environmental agents in the drop of flowers and fruits}

\section{Climatic and meteorological conditions}

Premature fruit drop is caused as a rule by a complex of different factors including at a high probability adverse environmental conditions (Soltész, 1997). Meteorological events before, during and following the development and vigour of flowers, bloom, fertilisation and flower subsequently fruit drop are highly decisive. In the moderate climate, the late frosts occurring in April and May, cause considerable damage on the blossom buds, flowers and young fruit primordia mainly by the destruction of important conductive tissues and causing fruit drop before and after fruits being set (Zatykó, 1999).

Temperatures prevailing during bloom are influencing immediately the vitality and longevity of the embryo sac, which already reduces the chance of fruit set. As long as the mean temperature remains below $17^{\circ} \mathrm{C}$, each degree of rise will diminish the life span of the embryo sac by one day. Low temperatures above the freezing point impair the vitality of embryo sac also. The damage may remain hidden and cause partial or total sterility of the flower and increases the rate of flower drop. Damages are expected also due to higher than normal temperatures.

A study was assigned to find out the role of temperature in the abscission of flowers during bloom of plum (Cerovic et al., 2000). Flowers were dropped as a consequence of deviations from temperature optimum for the egg cells. A high rate of flower drop was found at $20^{\circ} \mathrm{C}$, and it was less conspicuous at lower temperatures $\left(5,10,15^{\circ} \mathrm{C}\right)$, and the result depended on the variety too. Similar effects of high temperature have been revealed in apple and pear by Williams (1970), in cranberry by Cano-Medrano (1998).

The 5-7-week-long period after petal-shed are decisive from the point of view of fruit drop ( $L u \&$ Roberts, 1952; Westphal \& Stewels, 1970; Grauslund \& Hansen, 1975; Makino et al, 1986; Soltész, 1997). Immediately near to bloom, the low temperature, later the higher than optimal warmth is responsible for fruit drop, the latter by the stimulation of vigorous shoot growth (Soltész, 2002). After the cleaning drop, the importance of temperature in causing fruit drop declines.

Low temperatures applied after bloom to the apple variety 'Golden Delicious' diminished fruit drop, whereas in the pear 'Doyenné du Comice' applied after full bloom, 3-6 weeks later the effect was similar (Tromp \& Borsboom, 1994).

Spring frosts threaten first of all the most developed flowers within the inflorescences in apple and pear (Miranda, 2005) because the development of the flowers is related to their frost susceptibility (Baldini, 1992; Westwood, 1993). The more developed flower is the most vulnerable. In apple the apical, in pear the basal flower of the inflorescence is eligible to open first. As the first flower is damaged, the next, lateral flowers of the inflorescence have chances to grow a fruit. It may happen that in spite of the spring frost, more fruits are set due to the lateral flowers, and a fruit thinning will be necessary (Soltész, 1992).

Flowers being fertilised by autopollination are more susceptible to cold spells because there are less pollen tubes penetrating the ovaries, less growth substances are produced being expected to counteract the drop of flowers. The same is true for the young fruits. Fruits containing less seeds are inferior in frost resistance and are dropped at higher probability. 
Eggert (1960) argued in favour of the effect of the preceding temperature as an important factor responsible for the June drop of apple. Varieties are also distinct in tolerating exceedingly high temperatures. Some varieties are susceptible as 'Red Delicious', 'Cox's Orange Pippin' and 'Jonathan'. Less susceptible are 'Golden Delicious' and 'McIntosh', however, the latter becomes susceptible during the preharvest region. The susceptible varieties dropped fruits in June as an effect of high temperatures. The reduction of the number of fruits was associated with an increased size of fruits (Soltész, 1997).

Surányi \& Molnár (1981) refer also to the effect of temperature in the fruit drop of apricot. The authors reported that in 1972 severe fruit drop has been reported as a supposed effect of "catching cold". In late April, fruits are in full growth, and a cold spell even below zero affected at different degrees the fruits and some of them are shed others not. Fruit drop ensued most clearly close after the initial lignification of the stone (endocarp) at the mid of May. About the 34\% of the fruits of the tree were dropped. Some of the fruits shrivelled already up on the tree, whereas others dropped without being shrivelled.

It was observed that the progress of the lignification of the stone is associated with the reduction of the importance of fruit drop caused by environmental moments. The most frequent ones are the chill and the heat (Surányi \& Molnár, 1981). Under conditions of drought, the water absorption of the leaf is stronger than that of the fruit, therefore the fruits are more exposed to be dropped than leaves. The same was concluded also by Coit \& Hodgson (1919), who supposed that high temperature and low relative humidity caused in 'Navel' orange a high degree of June drop. It was claimed that by water stress in the leaves, water was absorbed from the juicy fruits, consequently, they warmed up and were dropped. Haas (1926) recognised the water loss of that type as an immediate cause of June drop. He stated that young fruits loose water at 2-3-times higher rate than the ripe ones first of all because the former are less cutinised and their surface/volume ratio is much higher.

The role of drought in fruit drop was recognised by the Hungarian Ministry of Agriculture (FVM (2002, 2003) and Papp (1984a, 1984b) in the case of gooseberry and black currant. Göndörné (2000) went to the same conclusions with 'Hardenpont winter butter pear' and Soltész \& Szabó (1998) and in 'Champion' apple. Puskás (2004) claimed that the dry springs are more prone to drop of fruits in stone fruit species.

Furr et al. (1939) stated that high temperatures are causing more fruit drop than chill and water stress of the soil. Hilgeman (1973) confirmed that contention by correlation coefficients between temperature and yields for the period of 1949-1971.

Gaash et al. (1993) attributes the high rate of preharvest fruit drop to warm and dry weather conditions of that period. High elevations above sea level are less afflicted by fruit drop (Lalatta \& Sansavini, 1983 cit. Soltész, 2002). Fruit varieties adapted to cooler climate are suffering at warm growing sites from high temperatures especially from the point of view of preharvest fruit drop.
Preharvest fruit drop is aggravated by wind and weather adversity (Nagy \& Kovács, 2005). The pear variety 'Hardy' is especially susceptible to wind (Göndörné, 2000). Where the local winds are severe, the plantations of pomaceous fruit species should be protected by windbreaks or hedges (Stösser, 2002).

Red fruit drop of sweet cherry is risked when cool and rainy weather is followed suddenly by a dry and hot period after the fruit set was important in the spring. Varieties react differently (Stösser, 2002).

Serdar \& Demir (2005) analysed the effect of the season on the fruit drop of hazel. It was reported that the subsequent years mean different conditions. In 2001, 7.50-9.33\%, in $20027.48-16.98 \%$ of the fruit bunches dropped. Seasonal effects on sour cherry were stressed by Nyéki (1978). The extent and the dynamics of fruit drop varied considerably. In 1972 more fruit was shed than in 1973. Out of the varieties examined as 'Pándy meggy-48' and 'Cigánymeggy-59' clones dropped less fruit in 1972.

Poor light conditions (e.g. shading) increase the incidence of fruit drop in sweet cherry (Patten \& Proebsting, 1986) and in other fruit species (Byers et al., 1991; CorelliGrappadelli, 2003). Adequate phytotechnical interventions applied for the purpose to secure better illumination (e.g. bending shoots, pruning) the number of fruits maintained on the tree is improved. The moderation of fruit drop was achieved also by the application of nocturnal red light for different length of time (Greene et al., 1986).

Thurzó et al. (2005) checked the fruit set and fruit drop of sweet cherry varieties at the four cardinal sides of the tree crown. The result was that southern and western sides set more fruit and less of them dropped, which was explained by the more favourable microclimatic conditions for pollinating insects (bees) and for the fertilisation of the flowers on the sides indicated.

\section{The influence of phytotechnical interventions on fruit drop}

A couple of experiments prove the necessity of interventions in order to produce optimal yield and better quality. Fruit thinning (Gonda, 1993; Soltész, 1997), regulation of water and nutrients (Coit \& Hodgson, 1919; Webber, 1923; Brewer et al., 1977; Palmer et al., 1977; Costa, 1978), phytosanitary means as well as harvesting techniques (Bukovac' et al., 1963; Surányi, 1978; Soltész, 1997) and the thoughtful combination of the above elements may reduce to a minimum of fruit lost by fruit drop.

Fruit thinning: It is designed to reduce the competition between the vegetative and generative organs as well as between the fruits, which is one of the main causes of fruit drop.

Soltész (1997) calls our attention to the right timing of fruit thinning in apple for the purpose to reduce losses caused by fruit drop. He stated that the thinning earlier than the June drop ensues is preferred if fruit size, flower bud formation and the increment of stem diameter are on the stake. Being prepared for the coming June drop, we should do it carefully 
as a preliminary thinning and final regulation should be timed after the June drop. A too earlier thinning may be also deleterious. Gonda (1993) claims that it is more costly and on the other hand a more important June drop is expected afterward. Within the recommended period, the earlier date is preferred if the flower bud initiation is favoured, whereas if the bud formation is not a matter of concern, rather the competition between fruits close to each other should be reduced. In apricot, a belated radical thinning may be followed by an unexpected heavy spontaneous fruit drop (Soltész, 1997).

The strive for an optimal leaf/fruit ratio was even more important at the earlier phases of development. The suppression of fruit thinning or its delay results in smaller fruits, moreover, the flower bud formation is hardly stimulated. Later a heavy fruit drop is risked especially in some apple varieties (e.g. 'Red Delicious', 'Spartan', 'Akane', furthermore, summer ripe varieties), which are prone to preharvest fruit drop. It would be a mistake to forget of fruit thinning expecting an important preharvest fruit drop (Soltész, 1997).

Irrigation, water supply: Completion for the restricted amounts of water is one of the causes of fruit drop. The role of watering is especially important on dry growing sites, or arid conditions.

The prevention of fruit drop immediately by irrigation is also known. The above crown water spray increases the air humidity within the canopy, moreover, the temperature of the leaves and fruits is lowered effectively by the evaporation (Brewer et al., 1977). By this way, the danger of fruit drop is largely reduced, temperature of the canopy being more important than humidity of the soil (Brewer et al., 1977; Costa, 1978).

It was also reported that heavy fruit drop may be caused also by excessive watering, which made split fruits near maturity (Anonymus, 2005a).

Nutrition: An overload of fruits is often considered to induce drop of young fruit because of the relative scarcity of nutrients (Tari, 2004c). Beginning with the blooming process, competition between flowers, subsequently, fruitlets and growing shoots produce the symptoms of shortage (Abruzzese, 1995). A couple of studies were assigned to explore this relation especially in apple production focussing on the prevention of fruit drop (Abbott, 1960; Luckwill, 1970). After the cleaning drop, the point of view of nutrition gains more importance gradually (Soltész, 2002).

Martinez et al. (1973) based their attempts on data raised by leaf analysis as to predict the imminence of fruit drop.

Papp (2003) accentuated the role of nitrogen being essential for a normal fruit set and later in avoiding the threatening June drop. Tarita et al. (1979) stated the same in relation of sour cherry, which could be saved from the first fruit drop by nitrogen.

According to Feucht (1970), on the other hand, excessive nitrogen, more than $21 \%$ content in the leaves, causes a heavy drop of fruits in blueberry. Szalai (2005) too dealt with the deleterious effect of excessive nitrogen causing accumulation of the poisonous nitrite leading to fruit drop.

Failla (1992) compared internationally raised data concerning the husbandry of nutrients in fruit plantations and refers to the table published by Greenham pointed to the uptake of nutrients of apple trees. The data presented serve for orientation only and suppose a plantation of 'Red Delicious' yielding $44.8 \mathrm{t} / \mathrm{ha}$. The whole volume of nutrients should include the flowers and fruitlets dropped, which represent an important fraction in spite of their relatively small quantity. The $\mathrm{N}$-content of the harvested crop was $58.7 \%$, P-content $28.1 \%$, and K-content $26.3 \%$, moreover, $\mathrm{Ca}$ and $\mathrm{Mg}$ was even more, $50-80 \%$, and all that at a high yield (44.8 t/ha). The $\mathrm{N}$ and $\mathrm{K}$ values are higher in peach because the dropped as well as maintained fruits have higher quantity of macro-elements than apple.

From the point of view of nutrient supply those are not considered because they are mobilised quickly in the soil and are recycled, but they call our attention to the significance of the whole tree and soil system and its dynamics (Szücs, 1999).

Abruzzese et al. (1995) studied thoroughly the apple variety 'Gloster' as its total nutrient supply including those found in dropped and maintained fruits and seeds. No significant difference was found in the content of reducing sugars, amino acids and proteins of fruits and seeds. However, $\mathrm{K}^{+}$and $\mathrm{Ca}^{2+}$ content were essentially more important in the fruits maintained on the tree than in the dropped ones (Figure 7). The concentration of water-soluble sugars (reducing as well as saccharose) was higher in the flesh of dropped fruits. $\mathrm{K}^{+}$and other water-soluble polysaccharides were more abundant in the fruits maintained on the tree.

Harvest: In the regulation of fruit drop, the timing of harvest fulfils an important role first of all in those varieties, which are prone to preharvest fruit drop, moreover, the technology of harvest is an important moment too especially in mechanical harvest.

In the case of using shakers (for thinning) working by the principle of vibration, some weeks away of fruit thinning, a posterior fruit drop is expected because of the scares of the peduncles (Bukovac et al., 1963). Also Surányi (1978) refers to the problems of the method: as most fruits are detached from the upper and outer region of the crown, although those fruits would develop sufficiently without intervention. Those are namely the most developed fruits of the tree.

\section{The role of biotic factors}

Flower and fruit drop is often caused by damages due to diseases and pests. The periodicity indicated above does not refer to the cases dealt with in the present chapter. It depends rather on the life cycle and behaviour of the organisms involved and their interaction with meteorological phenomena. Consequently, we have to refer to the critical periods of the growing season, when the symptoms of the damage used to appear. 


\section{Diseases}

The metabolism of the plants affected by a pathogen used to be altered in a characteristic way as summarised by Farkas cit. Haraszty (1978). The enzymatic patterns of the scared tissues display changes, which are similar to the symptoms of senescence also in healthy tissues, which are often leading to fruit drop. He argues that the metabolism of sick plants is analogous with that of a healthy but senescent plant, that means an anticipated senescence.

In the following, we may score the most important diseases, which are involved in premature flower or fruit drop. The symptoms of particular diseases are surveyed in order to identify the immediate cause of the abscission of the organs.

The abscission of vegetative organs is often caused by infection with Monilia. In peach, Taphrina is registered as most important, in all stone fruits the scab and in small fruits the grey mould is threatening. Most of the pathogens affecting flowers are promoting and speeding up the abscission (Singh et al., 2005).

Drop of flowers (or catkins) in walnut is the result of Xanthomonas infection. The male inflorescences (catkins) become brown or black. Later on, flower parts become deformed and abscise prematurely. Whole catkins are dropped entirely. The pathogen attacked also the fruit primordia, but are not dropped and shrivelled on the tree. According to breeders, the susceptibility of the known varieties is different. The varieties blooming earlier are more susceptible compared with the late blooming ones. Highly resistant varieties are still not known, but some partial resistance has been registered in the varieties 'Howe' and 'Franquette'. As most susceptible varieties the following ones are mentioned: 'Payne', 'Xerta 119', 'Xerta 122', 'VZ4', 'VZ5', 'FK5' and 'TR8', which were tested with Xanthomonas juglandis (Maria et al., 1997).

The fungus causing fruit rot (Monilinia fructicola) is generally recognised as initiating fruit drop. It is polyphagous and appears in many fruit species responsible for immediate preharvest fruit drop. A significant pathogen of larger fruits (apple, pear, apricot, peach) as well as smaller fruits (sweet and sour cherry, plum) and the affected fruits may rest on the tree overwintering as shrivelled mummies (Holb, 2003, 2004ab). Mink \& Jones (1996) claim that affected cherries are also abscised in some cases. This pathogen is a parasite penetrating through wounds and enjoys the scares caused by hail or pests. Around the point of penetration, a brown spot increases concentrically occupying gradually the whole fruit. The softened fruit is abscised at the upper end of the fruit stem without any abscission layer. The peduncle is often maintained on the tree if not abscised later. The most susceptible apple varieties to monilia fruit rot are 'Liberty', 'Golden Delicious', 'Freedom', 'Rome Beauty', 'Jonathan' and 'Sir Prize' (Holb, 2005). Holb \& Racskó (2005) proved that the susceptibility could be ignored in varieties, which are exposed to mechanical injuries and offer an easy way to the pathogen by the scares. Those scares may stem from cracks formed by rainy weather or sunscald. As susceptible varieties are registered 'Elstar', 'Red Elstar', 'Vista Bella', 'Royal Gala' apple varieties. The mechanically caused scares are large enough to initiate fruit drop. On wounds of sunscald are less susceptible to be affected by fruit rot, but are important in some varieties ('Jonica', 'Jonagold', 'Novayo'). The varieties less exposed to fruit drop are 'Stayman', 'Gala', 'Melrose', 'Akane' and 'Fuji'.

As a consequence of monilia-infection, hazel fruits get shrivelled and mummified within the hard pericarp during the dry weather of July. Also the fruit stem is brown and weakened being abscised finally. Mechanical scares are caused by the wind and by friction of branches. As measures against monilia the precaution from mechanical inferences and the elimination of dropped fruits could be recommended.

The leaf-curl disease of peach (Taphrina deformans) may appear also on the fruit as protuberances and discolorations. Even fruit drop may occur at vigorous infection. The susceptibility of peach varieties is displayed by different degrees observed on leaves and fruits until fruit drop as most. Most susceptible variety is 'Elberta' being used as a test; susceptible varieties are furthermore 'J.H. Hale', 'June Elberta', 'Bronzos Elberta', 'New July Elberta'; intermediately susceptible' Alexander', 'Amsden', 'Champion', 'Ford', 'Incrocio Morettini', 'Incrocio Pieri', 'Mayflower', 'Nektár-H', 'Piros Magdolna', 'Salvey', 'Steadley', 'Waddel', 'Tos China Octobre'. Varieties considered as resistant: 'Mezốkomáromi duránci', 'Miss Lolo', 'Michelini', 'Tardive Valla', 'Madelaine Pouyet', 'Avalon Pride', 'Curlfree', 'Frost', 'Indian Free', 'Mary Jane', 'Muir' and 'Q-1-8' (Koroknay, 1969; Körtvély, 1984). According to Benedek et al. (1990) 'Early Redhaven' and 'Loadel' are less susceptible to fruit drop caused by leaf curl of Taphrina. Kovács (1993) rated the following varieties as slightly susceptible: 'Aranycsillag', 'Cardinal', 'Loadel', 'Springtime' and 'Redhaven'. Recently, the following list is considered to be less susceptible: 'Early Redhaven', 'Elegant Lady', 'Harko', 'Hardired' and 'Maria Delizia', whereas very susceptible: 'Dixired', 'Elberta', 'Fantasia', 'Fiavortop', 'Independence', 'Michelini', 'Nectagrand-1', 'Red June', 'Snow Queen', 'Stark Redgold' and 'Venus' (Varga, 1995). Guttmann (1998) stated that in Hungarian peach plantations 'Dixired', 'Early Redhaven', 'Sunhaven', 'Suncrest' and 'Redcal' are less susceptible to leaf cur!.

Premature fruit drop caused by scab (Venturia carpophyla) in apricot and peach is particularly dangerous during a prolonged period of drought especially when water stress is experienced (EPPO). The first symptoms appear after the drop of petals during the $10-14^{\text {th }}$ week, initially on the green fruits as pale yellowish-green spots. On the flecks, dark brown velvet of conidia is visible. Later on, the increasing flecks get corky. The fruits shrivel subsequently and are dropped. Most susceptible are the late ripening apricot and nectarine varieties with the highest rate of fruit drop (EPPO). The same pathogen occurs though at lower rates on European plums too causing fruit drop.

Fruit drop of walnuts may be induced by Gnomonia too. Symptoms appear on the fruit (epicarp) only. The spots are 
initially small, slightly depressed, dark brown, later getting grey. Subsequently, large, irregular flecks are extending over the majority of fruit surface. The kernel may rot and the fruits are dropped prematurely. The species of the Juglans genus are variable in their susceptibility to Gnomonia. The different varieties of European walnut (Juglans regia) are les susceptible than those belonging to black walnut (Juglans nigra). As for the rest of walnut species and varieties grown in the USA, the Californian native Juglans hindsii and Juglans californica are susceptible at about the same degree as the European walnut, Juglans regia. The varieties exempt from this disease are 'Hartley' and 'Fayette', whereas 'J. Jefe' (S) and 'VZ5' are particularly susceptible (Maria et al., 1997). Among the varieties of black walnut 'Thomas' and 'Ohio' are considered as resistant, although some authors reported of cases, where a heavy infection pressure during a rainy season, both varieties were attacked (Berry, 1960).

Gooseberry, blueberry and blackberry are haunted by grey mould (Botrytis) causing fruit drop, finally. The afflicted berries display brown flecks, rot subsequently and are shed (Papp \& Porpáczy, 1999). It is largely favoured by a humid microclimate.

In Citrus species, fruit drop after bloom is caused by Colletotrichum acutatum. Its symptoms appear on the petals already, then, the flowers get brown and are shed as well as the young fruits (Timmer \& Brown, 2000; Li et al., 2003), although infection may anticipate fruit set. Lin et al.(2001) examined first the necrose of stigma and of style as affected by Colletotrichum acutatum and its relation to the postblooming fruit drop observed at the orange variety 'Temple'. Conspicuous losses are ascribed to that disease, which approach $100 \%$ without sanitary intervention ( $\mathrm{Li}$ et al., 2003). The pathogen may attack all cultivated Cytrus species except (Citrus aurantifolia) and limon (Citrus limon) varieties. Some orange varieties are very susceptible: 'Natal', 'Navel' and 'Valencia'.

\section{Pests}

Animal pests belong to the most frequently met agents causing fruit drop (Singh et al., 2005). The beetle (Omophlus proteus) lives preferably on sweet cherry (Bognár \& Huzián, 1974; Jenser et al., 1998). The imagines feed mainly on the flower parts, stamina and stigmata, moreover may destroy the pistil or young fruit primordium too. The fruit used to be drilled irregularly. The hurt flower or fruit primordium is fading and drop soon. The pest is found all over Cenral and South Europe (Jermy \& Balázs, 1990).

Flower parts (stamina and pistils) of fruit species (plum, apple, sour and sweet cherry, walnut and almond) are generally threatened by the imagines of maybeetle (Melolontha hippocastani) (Jenser et al., 1998), Phyllopertha horticola (Jermy \& Balázs, 1990) and the Japanese maybeetle (Popillia japonica) (Fleming, 1972; Jermy \& Balázs, 1990).

The damage caused by the hairy beetle (Epicometis hirta) is similar to that of the former ones. Its activity was described by a couple of authors (Györfy, 1934, 1935; Szilády, 1941; Kadocsa, 1947; Martinovich, 1962). The imagines start feeding on flowers of lower position eating preferably the pollen of the anthers, but may continue to bite the pistil too and cause fruit drop. They contribute mainly to the cleaning drop.

The red backed proboscide beetle (Coenorrhynchus aequatus) imagines start feeding on closed blossom buds and continue like the former beetles. The scared flowers and fruitlet are shed soon. After petal shed, oviposition ensues around the fruit stem in small holes. The larvae penetrate into the fruit and feed on the seeds. The preferred hosts are apple, pear, quince, plum, almond, hawthorn and rowanberry. The affected fruits stop growing, shrivel and are dropped gradually during the summer. Most observations refer to the damages found on apple and plum.

Another purple backed proboscid beetle (Rhynchites bacchus) is known all over Europe, Sibiria and Alger and feeds on apple, pear, plum, peach, apricot and almond. It also feeds on blossom buds and flower parts. After oviposition it chews the fruit stem without detaching the fruit definitely. The fruit is attacked when attaining the size of a nut, then the fruit is shrivelling gets mummified and is dropped later during the summer. Monilia-infection is often combined with the damage. Some scared fruitlets without containing larvae may remain attached to the tree and produce deformed and corky fruits. It is a periodically appearing pest, but a damage of $80 \%$ is not excluded (Glits et al., 1997).

The proboscid beetle of the hazel (Balaninus nucum) and of the oak (Balaninus glandium) brings up their larvae within the hard shell of the nut or acorn. They drill a hole of $\mathrm{cc} .2$ $\mathrm{mm}$ diameter and feed on the kernel. The beetle is the precursor of the fungus (Monilia fructigena) causing fruit drop, which may attain $70 \%$. Hazel varieties starting the hardening of the pericarp earlier ('Giant of Halle', 'Barcelona') are les threatened by the beetle, whereas a tender pericarp invites more beetles, e.g. 'Cosford' drop fruits according to Czencz (2002).

The peach moth (Anarsia lineatella) initiates fruit drop after having fed on the green stone fruits during the preharvest period (Reichart, 1965; Szegény, 1973). The attack ensues after the stone (endocarp) already hardened sufficiently. The point of penetration is either near to the fruit stem or where two fruits are touching eac6h other (Jermy \& Balázs, 1990). The ripening process is speeded up by the scare and a preharvest drop is initiated. On developed fruits gum used to appear. The door is also opened for monilia by the caterpillars. In the relevant literature peach, apricot, plum and almond was indicated as host plants in the decreasing order of frequency (Marlatt, 1898; Sajó, 1902; Sarra, 1916; Puppini, 1930; Summers et al., 1959). The plum varieties of yellow colour are preferred, but data are available referring also to apple, pear and different cultivated species of the genus Prunus as potential hosts (Bruel, 1934; Jones, 1935; Summers, 1949, 1955).

The moth (Spilonota ocellana) may also cause flower and fruit drop of the rate $5-10 \%$ in apple, quince, sweet cherry, peach, apricot and hazel (Kadocsa, 1938). The overwintering 
larvae start feeding on the flowers, eating stamina and pistils, later the fruits set are weaved around by the larger caterpillars hiding themselves beneath the web and feed on the growing fruit. The scared fruits are dropped continuously being often infected by fungi and rot (Jermy \& Balázs, 1990).

The oriental fruit moth (Grapholitha molesta) is mainly found on peach, apricot and on raineclaude-type of plums causing fruit drop. The caterpillars select mainly smaller fruits depending on the time of maturity, then feed on almost ripe fruits too. They attack the fruit near to the fruit stem and penetrate below the fruit skin and drill a shaft across the fruit flesh down to the ovary. The irregular cavities inside are filled with their droppings. On the surface appear extrusions of gum from the holes. The fruits are either dropped or start rotting due to fungal infection (Bodor \& Reichart, 1969). In almond and plum, fruit drop is rarely observed (Holb, 2005). Peach varieties of intermediate maturity ('Ford', 'Champion', 'Sunbeam') are particularly endangered and suffer from heavy preharvest drop.

The apple moth (Cydia pomonella) is responsible for high rates of fruit drop $(30-40 \%)$ in the several fruit species as apple, pear, quince, medlar and walnut (Garai, 2005). In the young fruit affected, a small, strait or slightly curved shaft approaches the ovaries. The pet foods of the caterpillar are the seeds, which are consumed exhaustively leaving only the empty testa and its droppings, occasionally some entire seeds too (Jermy \& Balázs, 1990; Jenser et al., 1998). The larvae of the first generation damage 2 or 3 fruitlets, whereas for the second generation 1 or 2 fruits are sufficient (Glits et al., 1997). The scared fruits drop as a rule in June or July. In walnut, the pericarp becomes black and shrivelled without being split. On the basal side, a small hole is the proof of penetration, and the fruits are astray on the floor.

In Hungary, observations of old apple varieties started already during the last century. In 'Húsvéti Rozmaring' the damage was more severe than in 'Batul' (Szelényi et al., 1953). In 'Jonathan' the fruit drop was more important than in 'London Pippin' (Husz, 1949). 'Winter Gold Parmain' and 'Cox's Orange Pippin' were the most suffering apple varieties; therefore they are used as indicators of the presence of the pest. Nagy (1976) proved that 'Golden Delicious' is more susceptible than 'Jonathan' and 'Starking'. 'Elstar', 'Idared' and 'Jonagold' are susceptible to the apple moth and drop fruits (Rasztik, 2003).

In walnut, the damage may attain in susceptible varieties $11 \%$. Differences between varieties are important. In ,papershelled" are more affected than hard-shelled ones (Körtvély, 1978). Most resistant were 'Alsószentiváni 117' and 'Tiszacsécsi 2' more than 'Fertôdi E1' and 'Tiszacsécsi 14'. American date prove that 'Hartley' and 'Chandler' start growing later, therefore avoid the apple moth as well as the drop caused by Xanthomonas infection (Holb, 2005).

The moth (Grapholitha lobarzewskii) is also found on fruits of apple and plum. The small larvae drill a shaft underneath the skin of the fruits according to a circular pattern, and then penetrate to the seeds. With the scaring of seeds, the fruit looses the source of auxin and is abscised. In Hungary, its incidence does not exceed $1-2 \%$.

Similar damage is expected from the pear moth (Laspeyresia pyrivora), however, this pest appears only in the wild growing and cultivated pear as hosts, being monophagous (Jenser et al., 1998). The caterpillar is feeding also on the seeds within the fruit (Glits et al., 1997). In Hungary, its incidence is around 3-8\%. Between the pear varieties no essential differences are stated from the point of view of resistance (Pálfi, 1971; Holb, 2005). Most damage has been stated under Hungarian condition in 'Beurré Bosc', 'Doyenné d'Hiver', 'Bonne Louise d'Avranches', 'Curé', 'Olivier de Serres', 'Beurré Diel' (Pálfi \& Wiandt, 1970).

In May and early June, the plum moth (Grapholitha funebrana) attacks the green fruits of minor size, as small holes and gum extrusions appear. The deformation of the fruits is associated with premature drop of fruits. As mentioned at the former moths, the damage is often combined with fungal infection like Monilia. No varietyspecific differences in susceptibility/resistance have been claimed yet, but the tendency of more serious damage is attributed to the varieties of late maturity (Deseô, 1966). Deseô et al. (1971) contended that the diminishing order of fruit drop is represented by the following series: 'Ageni', 'Besztercei kései', 'Olaszkék', 'Kék ringló', 'Besztercei korai'.

The small winter looper (Operophtera brumata) and the large winter looper (Erannis defoliaria) caterpillars attack leaves and also the tender green fruitlets, e.g. of cherry, plum, apricot, and scare several fruit near to each other, and eat the seed within the endocarp being still soft. The fruits are doomed to be dropped.

The Mediterranean fruit fly (Ceratitis capitata) is also polyphagous with great many host plants. The larvae prefer the fruits of Cytrus species, but are found in apricot, peach, pear, apple, plum, cherry and in couple of non cultivated juicy fruits. The scared fruits start browning, softening, depressions appear on their surface. The flesh of the fruit becomes creamy, mucilaginous and start rotting dropped on the soil.

The black wasp of the plum (Hoplocampa minuta) and the yellow one (Hoplocampa flava) appears on European plum and other plums. The stone of the attacked fruit used to be empty because the larvae eat the kernel (Glits et al., 1997). The larvae and the damaged fruits are easily recognised by the peculiar smell reminding of bugs. The larvae relinquish the fruits dropped on the floor within 1 or 2 hours in sunny weather, whereas 1 or 2 days are needed on a shadowed site. That fruit drop is mainly found in early ripening plum varieties. The damage may attain 50-90\%. As young fruits are most endangered, the varieties with a lagging bloom period are exposed to the damage.

The pear fruit-wasp (Hoplocampa brevis) is closely related to the former species and its damage resembles too except that the flowers are also attacked. The larvae freshly hatched start feeding on the pistil of the flowers. Between the stamina and pistil it is drilling a shaft in a half circle, which 
is recognised by its black discoloration. Those flower are doomed to abscission. The small fruit primordia are then shed in masses and the dark holes are traced on the dropped fruitlets associate by the brown droppings of the small pseudo-caterpillar. The first attacked pear may survive and it bears the signs of the damage being deformed at the apical part of the fruit. The second and third young fruit attacked up to the size of a hazel are also recognised but they are shed suddenly later.

The apple wasp (Hoplocampa testudinea) is specialised to the apple. The larvae drill a hole into the fruitlet and reddish brown or black juice appears at the entrance of the hole. The young fruits of the size of a hazel of nut are shed in masses and the white larvae are identified within them. The damage caused by the apple moth is timed differently. The fruit drop attributed to the wasp ensues earlier, i.e. until mid of June (whereas at the end of June in the mountains) and the fruit drop of the apple moth starts later by $1-2$ weeks.

Flower and fruit drop in raspberry is caused by the small raspberry beetle (Byturus tomentosus). The imagines feed on the pollen and nectarines chewing on the blossom buds already. The attacked buds are often shed (Jermy \& Balázs, 1990) or as scared fruits are dropped as deformed fruits during the summer. The larvae drill shafts into the receptacle and pistils, later into the growing fruits. Other species of the genus Rubus are also host plants of the beetle, moreover, fruit species as apple, pear, cherry and species of the Prunus genus are also attacked during July and August (Ubrizsy, 1968). The drop of flowers and young fruits may occur up to 20-30\% (Tóth, 1965; Jermy \& Balázs, 1990; Jenser et al., 1998; Holb, 2005).

Near to the harvest time, birds may cause fruit drop too. As commonly recognised, the starling (Sturnus vulgaris) is feeding in large flocks and scares the fruits as soon as they are soft enough.

\section{Aknowledgement}

Present study was partially supported by the grant OTKA K63065, Hungarian State Eötvös Scholarship and OMFB 00909/2005. of the National Office for Research and Technology (NKTH).

\section{References}

Benedek, P., Nyéki, J. \& Vályi, I. (1990): Csonthéjas gyümölcsfajták érzékenysége a fontosabb kórokozókkal és kártevốkiel szemben - A fajtaspecifikus növényvédelmi technológia kidolgozása. Növényvédelem 26 (1): 12-31.

Berry, F.H. (1960): Etiology and control of walnut anthracnose. Univ. Md. Agric. Exp. Stn. Bull. A-113: 22.

Bodor, J. \& Reichart, G. (1969): Keleti gyümölcsmoly (Grapholita molesta Busck) Magyarországon. A növényvédelem korszerûsítése 3: 63-83.
Catlin, P.B., Ramos, D.E., Sibbett, G.S., Olson, W.H. \& Olsson, E.A. (1987): Pistillate flower abscission of the Persian walnut. HortScience 22 (2): 201-205.

Czencz, K. (2002): A mogyoró kártevối. p. 211-215. In: Radócz, L. (ed.): A héjasok növényvédelme. Szaktudás Kiadó Ház, Budapest.

Deseô, K. (1966): A szilvamoly (Grapholita funebrana Tr.) elleni védekczés. Növényvédelem 2 (6): 262-269.

Deseô, K., Sáringer, Gy. \& Seprốs, 1. (1971): A szilvamoly (Grapholita funebrana Treitscheke). Mezôgazdasági Kiadó, Budapest.

Glits, M. - Horváth, J. - Kuroli, G. - Petróczi, I. (eds.) (1997): Növényvédelem. Mezógazda Kiadó, Bp. 661.

Gomez-Cadenas, A. - Mehouachi, J. - Tadeo, F.R. - PrimoMillo, E. - Talon, M. (2000): Hormonal regulation of fruitlet abscission induced by carbohydrate shortage in citrus. Planta. 210: 636-643.

Goren, R. (1993): Anatomical, physiological, and hormonal aspects of abscission in citrus. Hort. Rev. 15: 145-182.

Goren, R. - Goldschmidt, E.E. (1970): Regulative systems in the developing citrus fruit. I. The hormonal balance in orange fruit tissues. Physiol. Plant. 23: 937-947.

Göndör, J.-né (1998): Körte. In: Soltész, M. (1998): Gyümölcsfajta-ismeret és -használat. Mezôgazda Kiadó, Budapest. 156-186.

Göndör, J.-né (2000): A körte fajtahasználata és nemesítésc. In: Göndör, J.-né (szerk.) (2000): Körte. Mezógazda Kiadó, Budapest. $102-150$.

Greene, D.W. (1989): CPPU influences McIntosh apple crop load and fruit characteristics. HortScience. 24: 94-96.

Greene, D.W. - Craker, L.E. - Brooks, C.K. - Kadkade, P. Bottecelli, C. (1986): Inhibition of fruit abscission in apple with night-break red light. HortScience. 21: 247-248.

Guinn, G. - Brummett, D.L. (1988): Changes in free and conjugated indole-3-acetic acid and abscisic acid in young cotton fruits and their abscission zones in relation to fruit retention during and after moisture stress. Plant Physiol. 86: 28-31.

Guttmann, V. (1988): Ökológiai szemléletũ gazdálkodás tapasztalatai az EUROTRUST Consult Kft. ốszibarack ültetvényeiben. Kertgazdaság 30 (3-4): 84-93

Haraszty, Á. (ed.) (1978): Növényszervezettan és növényélettan. Nemzeti Tankönyvkiadó, Bp. 798.

Holb, I. (ed.) (2005): A gyümölcsösök és a szôlố ökológiai növényvédelme. Mezốgazda Kiadó, Budapest 340.

Holb, I. J. (2003): The brown rot fungi of fruit crops (Monilinia spp.) I. Important features of their biology (Review). International Journal of Horticultural Science $9(3-4): 23-36$.

Holb, I. J. (2004a): The brown rot fungi of fruit crops (Monilinia spp.) II. Important features of their epidemiology (Review). International Journal of Horticultural Science 10 (1): 17-35.

Holb, I. J. (2004b): The brown rot fungi of fruit crops (Monilinia spp.) III. Important features of their disease control (Review). International Journal of Horticultural Science 10 (4): 31-48. 
Husz, B. (1949): Beszámoló az 1948. évi almafapermetezési kísérletekrổl. Agrártudományi Egyetem Kertészeti és Szôlészeti Kar Közleményei 13: 235-242.

Jenser, G. - Mészáros, Z. - Sáringer, Gy. (ed.) (1998): A szántóföldi és kertészeti növények kártevói. Mezốgazda Kiadó, Budapest.

Jermy, T. \& Balázs, K. (1990): A növényvédelmi állattan kézikönyve 3/A-B. Akadémiai Kiadó, Budapest, 673.

Kavetskaja, A.A. \& Tokar, L.O. (1963): Otritsatel'noe deystivie bol'shogo kolichestva pyl'tsy pri opylenii gretskovo oreha. Bot. Zhur. 48(4): 580-585.

Koroknay, B. (1969): Ốszibarackfajták érzékenysége a tafrinás levélfodrosodással szemben. Növényvédelem 5 (6): 15-19.

Kovács, J. (1993): Az alma- és ôszibarackfajták érzékenysége fertôzố betegségekkel és kártevốkkel szemben. PhD Thesis. MTA, Budapest, 191. pp.

Körtvély, A. (1978): Almamoly elleni védekezés dioúltetvényben. Múszaki Fejlesztési Eredmények 19: 1-2.

Körtvély, A. (1984): Az ốszibarack tafrinás levélfodrosodása, In: Jenser, G. (ed.): Gyümölcsfák növényvédelme. Mezốgazdasági Kiadó, Budapest p. 72-74.

Li, W. - Yuan, R. - Burns, J.K. - Timmer, L.W. - Chung, K. (2003): Genes for hormone biosynthesis and regulation are highly expressed in citrus flowers infected with the fungus Colletotrichum acutatum, causal agent of postbloom fruit drop. J. Amer. Soc. Hort. Sci. $128(4): 578-583$.

Maria, P., Donatella, C. \& Gennaro, C. (1997): Susceptibility of 32 walnut varieties to Gnomonia leptostyla and Xanthomonas campestris pv. juglandis. Acta Hort. 442: 379-384.

Martinovich, V. (1962): A bundásbogár (Epicometis hirta Poda) kártétele, elterjedése, rajzásvizsgálata Magyarországon. Fol. Ent. Hung. 15: 347-364.
Nagy, B. (1976): Presence and use of natural food sources of the codling moth (Laspeyresia pomonella L.) in Hungary. Coll. Int. CNRS 265: 211-225.

Pálfi, D. (1971): Körtemoly (Laspeyresia pyrivora Dan.). PhD Thesis. Kert. Egyetem, Budapest.

Pálfi, D. \& Wiandt, H. (1970): A körtemoly (Laspeyresia pyrivora Dan.) hazai elöfordulásának és vizsgálatának eredményei Zala megyében. Növényvédelem 6: 251-254.

Papp, J. - Porpáczy, A. (ed.) (1999): Bogyósgyümölcsúek II. Szeder, ribiszke, köszméte, különleges gyümölcsök. Mezốgazda Kiadó, Bp. 246.

Pór, A. - Pór, J. (1990): The effect of the excess of pollen on the fruitset of walnuts in Balatonboglár. Acta Hort. 284: 253-256.

Rasztik, V. (2003): Az ökokertek növényvédelme. Mezôgazda Kiadó, Budapest. 277.

Singh, Z. - Malik, A.U. - Davenport, T.L. (2005): Fruit drop in mango. Horticultural Reviews. 31: 111-153.

Szelényi, G., Terényi, S. \& Viktorin, A. (1953): Az almamoly kérdés és az 1947-1951. évi védekezési kísérletek eredményei. Növényvéd. Kut. Int. Kiadv. 3:1-10.

Szentiványi, P. (1990a): Effect of fertility auto-regulation on productivity of walnut. Acta Hort. 284: 251.

Szentiványi, P. (1990b): Effect of fertility-autoregulation on variety-combinations of walnut. Acta Hort. 284: 257-260.

Szentiványi, P. (2000): Dió és gesztenye fajtakutatás. In: 50 éves a gyümölcs és dísznövény kutatás. Budapest-Érd, 12-13.

Timmer, L.W. - Brown, G.E. (2000): Biology and control of anthracnose discases of citrus, p. 300-316. In: Prusky, D. - Freeman, S. - Dickman, M.B. (ed.) (2000): Colletotrichum: Host specificity, pathology, and host-pathogen interaction. APS Press, St. Paul, Minn. Varga, L. (1995): Ốszibarackfajták Taphrina deformans iránti fogékonysága. Új Kertgazdaság 1 (3): 73. 